\title{
Evaluation of Pharmacognostic, Phytochemical and Physicochemical Standards of Wedelia Trilobata (L.) Root
}

\section{Prasanth DSNBK* and Lakshmana Rao A}

Department of Pharmacognosy, V. V. Institute of Pharmaceutical Sciences, India

*Corresponding author: Prasanth DSNBK, Associate Professor, Department of Pharmacognosy, V. V. Institute of Pharmaceutical Sciences, Gudlavalleru, Andhra Pradesh, India, Tel: +917382027437; Email: dsnbkprasanth@gmail.com

\section{Research Article}

Volume 2 Issue 1

Received Date: January 11, 2018

Published Date: January 29, 2018

\section{Abstract}

Context: Ethnomedicinally, the root of Wedelia trilobata L. (Asteraceae) has long been used in various ailments in traditional system; most importantly it is used against backache, muscle cramp, rheumatism, stubborn wounds, sores, swelling and arthritic pain, fever and malaria. The main problem experienced in the standardization of herbal drugs is lack of proper identification of plant source. So there is need to establish quality control parameters by using pharmacognostic and phytochemical evaluation, which ensures the purity, safety and efficacy of medicinal plant W. trilobata.

Aim: To evaluate pharmacognostic properties including macroscopic, microscopic and physicochemical parameters of the root of W. trilobata.

Methods: Micro and Macroscopic characters of fresh and dried root samples were investigated. Physicochemical parameters were done by utilizing WHO recommended parameters, preliminary phytochemical and fluorescent analysis of root sample were performed for identification and standardization of root of W. trilobata.

Results: The color, shape, size, odor and surface characteristics were noted from the root and powdered root material of W. trilobata. Light electron microscope images of cross section of root and powdered root revealed that the presence of cork cells, lignified spiral vessels, and parenchymatous cells. Phytochemical screening showed the presence of flavonoids, tannins, phenols, saponins, steroids, carbohydrates and glycosides. Physicochemical parameters such as moisture content, ash value, extractive value and fluorescent behavior of root powder were determined. These parameters are useful tools to differentiate the powdered drug material.

Conclusion: The present study is helpful to supplement the information with regard to its standardization and identification and in carrying out further research in Ayurvedic system of medicine.

Keywords: Pharmacognostic; Microscopical; Wedelia trilobata L; Physicochemical and lignified spiral vessels 


\section{Open Access Journal of Pharmaceutical Research}

\section{Introduction}

The procedure of standardization is achieved by pharmacognostic studies that assist in authentication and identification of plant materials. Proper quality and identification assurance of the raw materials are crucial in herbal treatment to insure their quality, safety and efficacy. Pharmacognosy could possibly be a dependable and easy device, by that total information of the crude medication is obtained. The majority of the pharmacopeias and regulatory recommendations are suggested macroscopic and microscopic analysis and chemical substance profiling of natural components for quality control and standardization [1] Wedelia trilobata (L.) Hitchc (Synonym: Sphagneticola trilobata (L.) Pruski), belonging to the Asteraceae family and native to South America, is a perennial creeping herb which is known as an invasive plant at many tropical and subtropical areas including southern China [2,3]. W. trilobata is an herbaceous creeping perennial shrub, up to $70 \mathrm{~cm}$ height, forms dense mounded mats over the ground. Leaves are glossy green, paler green below, with simple coarse white hairs, serrated margins, sometimes with a pair of lateral lobes.

The stem is rounded, rooting at nodes, stolons up to $2 \mathrm{~m}$ in length or more. Flowers are borne on solitary or branched inflorescences, ray florets yellow (8-13 per head), central disc florets yellow and tubular, flowers freely produced throughout the year in warm tropics. Fruits are 3-cornered nuts, very small $(3-5 \mathrm{~mm})$, with corky covering and topped by short scales, mature from green to brown, dispersed by water. New plants arise from nodes that root at the soil surface. Seed production is low and generally does not reproduce prolifically via seed [4]. It really is utilized by Indians as traditionally in the treatment of backache, muscle cramp, rheumatism, stubborn wounds, sores, swelling and arthritic pain, fever and malaria [5-7]. So far, phytochemical studies have revealed some structurally diverse chemicals from this plant, including terpenoids (sesqui-, diter-, and triterpenoids), steroids, flavonoids and phenolics, some of which showed significant bioactivities [7-13]. Numerous pharmacological activities of $\mathrm{W}$. trilobata offers been reported such as antimicrobial [14], Antioxidant [15], Anti-inflammatory [15], wound healing [16], Anthelmintic [17] and anticancer [15].

Therefore, we make an effort for standardization of Wedelia trilobata L. root to study the morphological, anatomical, physicochemical and preliminary phytochemical evaluation of root was carried out.

\section{Material and Methods}

\section{Plant Material and Authentication}

Wedelia trilobata L. Plant was procured in the month of September 2017, from V. V. Institute of Pharmaceutical Sciences, Gudlavalleru, Andhra Pradesh. It had been recognized and authenticated by K. Madhavachetty, plant taxonomist, Division of Botany, Sri Venkateswara University, Tirupati, Andhra Pradesh and voucher specimen of the plant was deposited at the herbarium for long-term reference.

\section{Pharmacognostic Evaluation}

Organoleptic evaluation: Organoleptic characteristics of Wedelia trilobata root was assessed by observing color, odor, taste, shape and size according to WHO quality control methods for herbal medicine [18-20].

\section{Microscopic Evaluation}

Preparation of sections: Free handed sections of the root were cut into thin sections manually with the sharp cutting edge of the blade. Then transferred on the slide, cleared by warming with chloral hydrate, stained with phloroglucinol and Conc. $\mathrm{HCl}$ and mounted in glycerin. The lignified and cellulosic tissues were recognized by utilizing different staining techniques [18].

\section{Powder Microscopy}

The powder microscopy was performed according to the method mentioned in Khandelwal [18].

Physicochemical analysis: Physicochemical parameters such as ash value, moisture content and extractive values were determined according to the procedures mentioned in WHO quality control methods for herbal materials [1820].

Phytochemical analysis: Chloroform, ethyl acetate, ethanol and water extracts of Wedelia trilobata L. were subjected to qualitative chemical analysis of various phytoconstituents like alkaloids, glycosides tannins, flavonoids, steroids and volatile oils according to methods of Khandelwal [18,20-22].

Preparation of extract: The root of Wedelia trilobata was shade dried and powdered. 100g of powdered root was subjected to cold maceration by increasing order of polarity viz chloroform, ethyl acetate, ethanol and water. After $24 \mathrm{hrs}$ filtered the extracts and concentrate with the help of rotary evaporator.

Fluorescence analysis of the powdered drug: The fluorescence examination of the plant material was done by placing the dry powdered root on a slide and observing 


\section{Open Access Journal of Pharmaceutical Research}

by treating with a few drops of different chemical reagents to detect the color changes under UV and visible light $[18,23]$.

\section{Results}

\section{Pharmacognostic Evaluation}

Organoleptic and microscopic evaluation: The Organoleptic characteristics of root showed in Table 1 . The transverse section of root is found to be circular in outline. The epidermis is the outer most layer it is made up of cuboidal shaped cells, which are arranges compactly without any intercellular sapaces. The outer layer consists of many uniseriate multicellular hairs. The hypodermal layer is composed of parenchymatous cells with some intercellular spaces. The endodermis showed the presence of phloem and xylem. The phloem is present in between the medullary rays. The medullary rays are parenchymatous and are biserrate in nature. Phloem is well developed and shows the presence of phloem fibres, which are lignified. It also showed the presence of phloem parenchyma. The xylem region was similar to phloem region and was also surrounded by biserriate. Xylem tissue consists of spiral xylem vessels, xylem fibres and xylem parenchyma as shown in Figure 1 to 6.
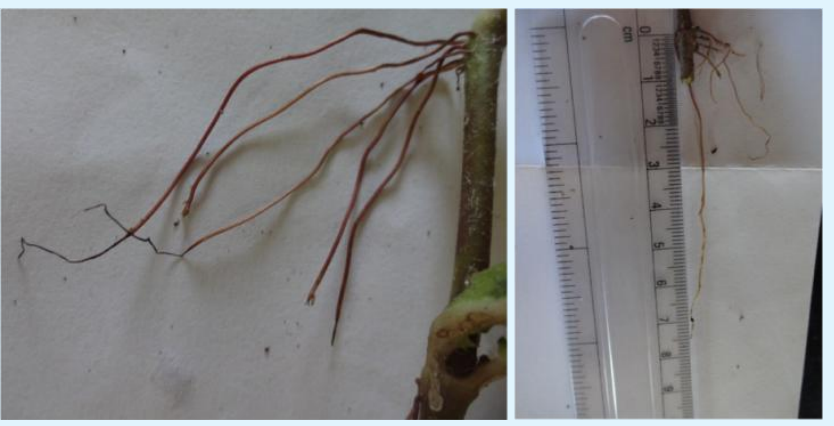

Figure 1: Morphological Characteristics of Wedelia trilobata L. Root.

\begin{tabular}{|c|c|}
\hline Organoleptic characters & Observation Root \\
\hline Colour & Buff \\
\hline Odour & Characteristic \\
\hline Taste & No taste \\
\hline Size & 5 to $14 \mathrm{~cm}$ \\
\hline Texture & Smooth \\
\hline
\end{tabular}

Table 1: Organoleptic Characteristics of Wedelia trilobata L. Root

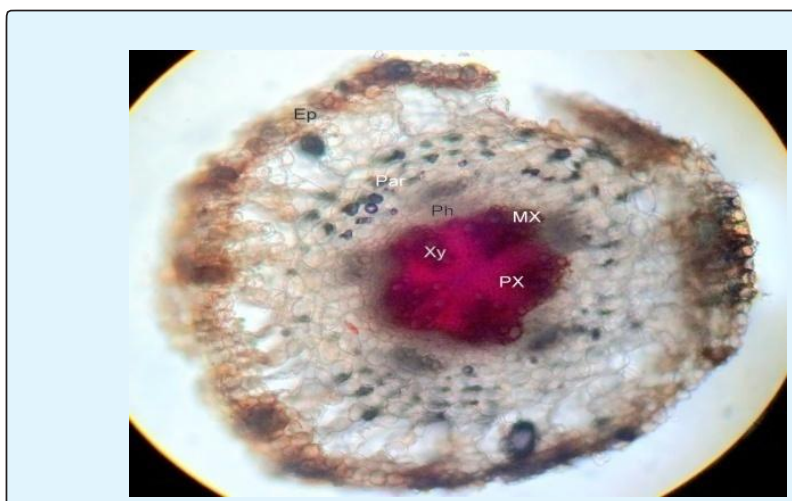

Figure 2: Transverse section of Root of Wedelia trilobata L. Ep: Epidermis; Par: Parenchyma cells; Ph: Phloem; Mx: Meta Xylem; PX: Proto Xylem and Xy: Xylem.
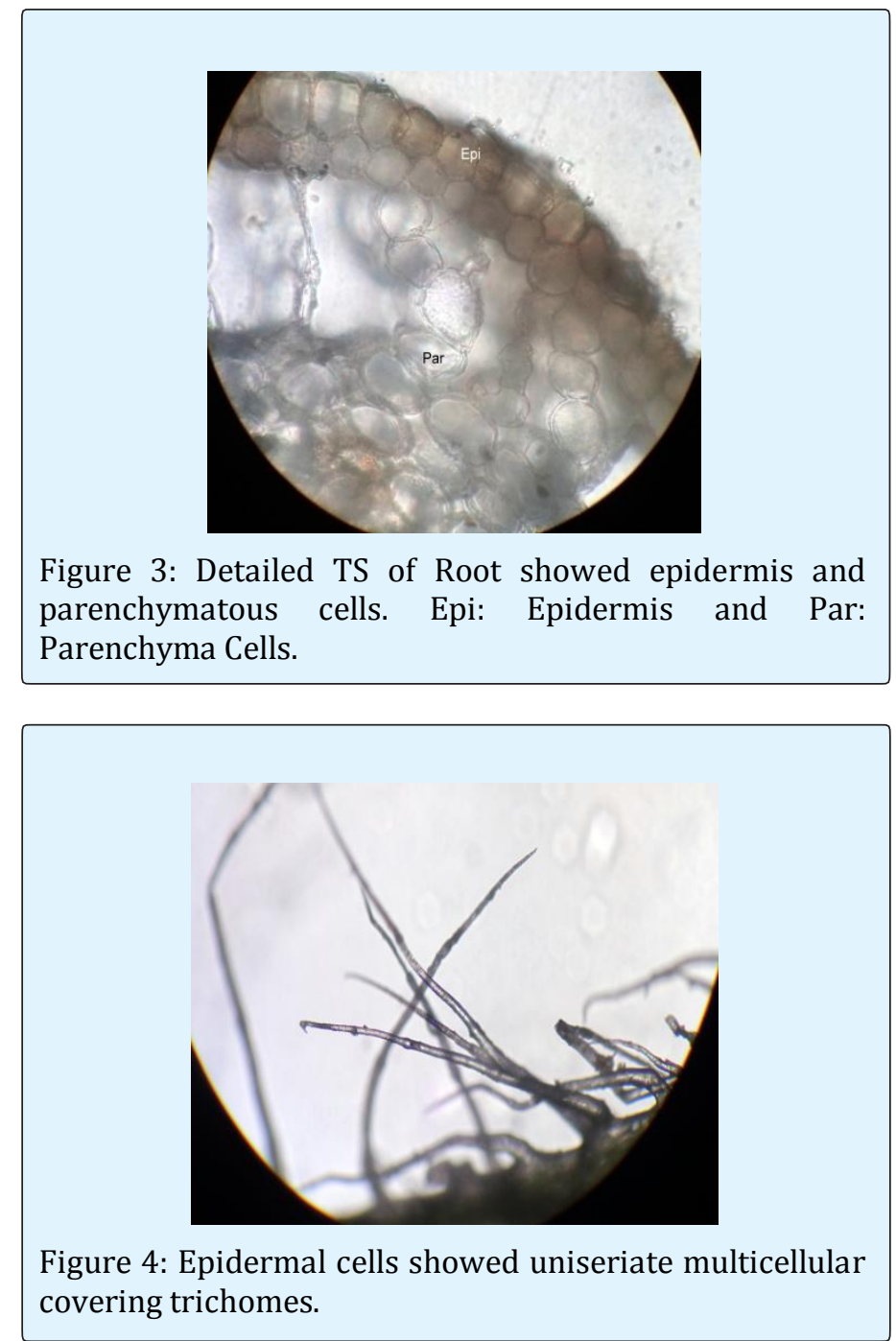


\section{Open Access Journal of Pharmaceutical Research}

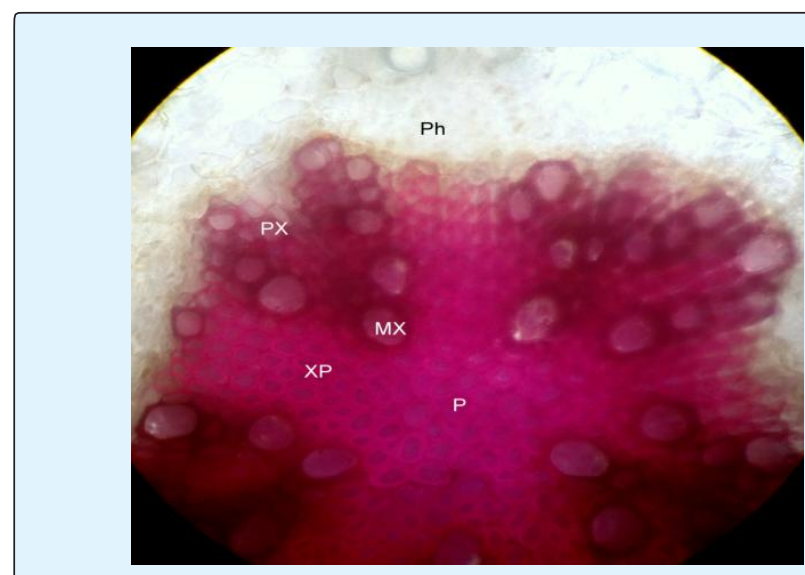

Figure 5: T.S of Root portion of Wedelia pilosa L. showed Vascular Bundles. Ph: Phloem; PX: Proto Xylem; Mx: Meta Xylem; XP: Xylem Parenchyma; P: Pith.

Powder microscopy: The powder plant material is buff in color, showed lignified spiral vessels, parenchyma, cork cells, medullary rays and Xylem vessels as shown in Figure 6

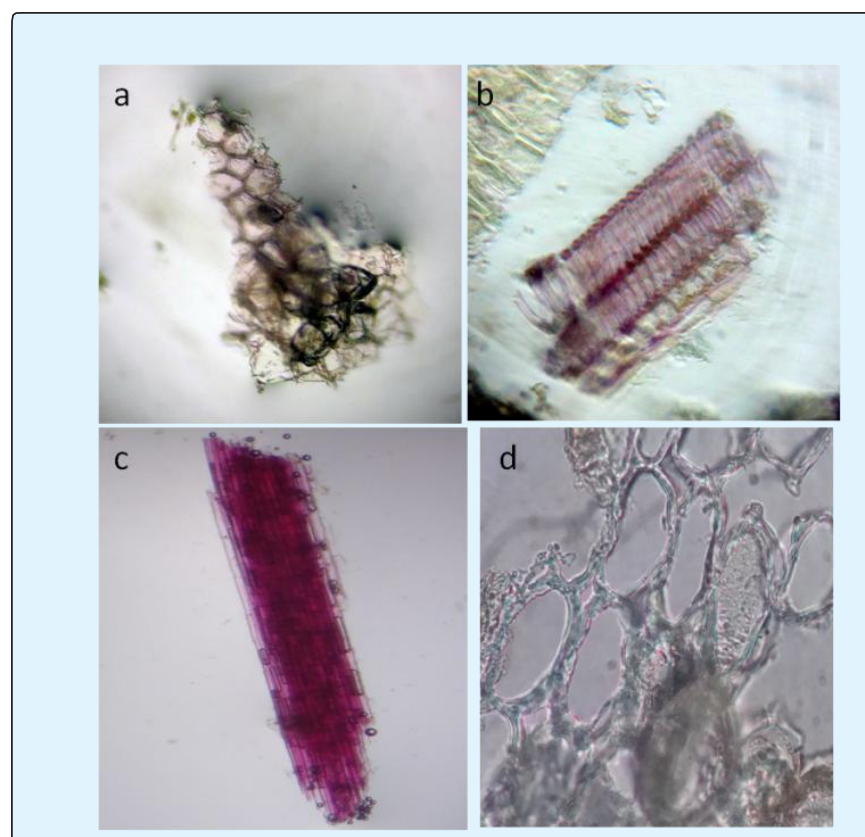

Figure 6: Powder microscopy of Wedelia trilobata Root. (a) Cork cells (b) Lignified Xylem vessels (c) Lignified Fibres (d) Parenchyma cells.

Physicochemical evaluation: The various physicochemical parameters of root and root powder i.e., loss on drying, ash value and extractive value were determined. The total ash, acid insoluble ash, water soluble ash, petroleum ether soluble, chloroform soluble, ethyl acetate soluble, alcohol soluble and water-soluble extractive values were shown in Table 2.

\begin{tabular}{|c|c|}
\hline Parameters & Values $\mathbf{~ \% w / w ~}$ \\
\hline Moisture content (Loss on drying) & $9.23 \pm 0.23$ \\
\hline Total ash & $12.25 \pm 0.56$ \\
\hline Acid-insoluble ash & $4.5 \pm 1.58$ \\
\hline Water soluble ash & $2.51 \pm 0.86$ \\
\hline $\begin{array}{c}\text { Petroleum ether soluble extractive } \\
\text { value }\end{array}$ & $1.82 \pm 0.05$ \\
\hline Chloroform soluble extractive value & $3.84 \pm 0.44$ \\
\hline Ethyl acetate soluble extractive value & $5.66 \pm 0.66$ \\
\hline Alcohol soluble extractive value & $9.85 \pm 1.85$ \\
\hline
\end{tabular}

Table 2: Physicochemical Parameters of root powder of Wedelia trilobata L.

Preliminary phytochemical screening: The preliminary phytochemical screening of the extracts viz., chloroform, ethanol, and water was carried out and the results obtained shown in Table 3.

\begin{tabular}{|c|c|c|c|c|}
\hline \multirow{2}{*}{$\begin{array}{c}\text { Phyto } \\
\text { constituents }\end{array}$} & \multirow{2}{*}{ Method } & \multirow{2}{*}{\begin{tabular}{|c|} 
Aqueous \\
Extract
\end{tabular}} & \multicolumn{2}{|c|}{ Ethanol Chloroform } \\
\hline & & & Extract & Extract \\
\hline \multirow{3}{*}{ Flavonoids } & Shinoda Test & + & + & - \\
\hline & \begin{tabular}{|c|} 
Zn. \\
Hydrochloride \\
test
\end{tabular} & + & + & - \\
\hline & \begin{tabular}{|c|} 
Lead acetate \\
Test
\end{tabular} & + & + & - \\
\hline Volatile oil & Stain test & - & - & - \\
\hline \multirow{2}{*}{ Alkaloids } & Wagner Test & - & - & - \\
\hline & Hager's Test & - & - & - \\
\hline \multirow[b]{2}{*}{$\begin{array}{l}\text { Tannins \& } \\
\text { Phenols }\end{array}$} & $\mathrm{Fecl}_{3}$ Test & + & + & - \\
\hline & $\begin{array}{c}\text { Potassium } \\
\text { dichromate } \\
\text { test }\end{array}$ & + & + & - \\
\hline Saponins & Foaming Test & + & + & - \\
\hline Steroids & Salkowski test & + & + & + \\
\hline Carbohydrates & Molish test & + & + & - \\
\hline $\begin{array}{c}\text { Acid } \\
\text { compounds }\end{array}$ & Litmus test & - & - & - \\
\hline Glycoside & \begin{tabular}{|c} 
Keller-Killani \\
Test
\end{tabular} & + & + & - \\
\hline Amino acids & Ninhydrin test & - & - & - \\
\hline Proteins & Biuret & - & - & - \\
\hline
\end{tabular}

"+" Present and "-" Absent

Table 3: Phytochemical analysis of various extracts of Wedelia trilobata L. Root 


\section{Open Access Journal of Pharmaceutical Research}

Fluorescence analysis: The behavioral changes of the powdered drug with distinctive chemical reagents were determined at both UV and Visible light and it is reported as shown in Table 4.

\begin{tabular}{|c|c|c|c|}
\hline Solvent used & $\begin{array}{c}\text { Visible } \\
\text { light }\end{array}$ & $\begin{array}{c}\text { UV light At } \\
\text { short (254nm) }\end{array}$ & $\begin{array}{c}\text { At Long } \\
\text { (366nm) }\end{array}$ \\
\hline Distilled water & Buff & Buff & Dark Brown \\
\hline $\begin{array}{c}1 \mathrm{~N} \mathrm{NaOH} \mathrm{1N} \\
\text { Methanol }\end{array}$ & Brown & Black & Black \\
\hline $1 \mathrm{~N} \mathrm{HCl}$ & Buff & Reddish brown & Black \\
\hline $50 \% \mathrm{HNO}_{3}$ & Brown & Brownish white & Black \\
\hline $\mathrm{FeCl}_{3}$ & Buff & Yellowish brown & Bluish red \\
\hline $\mathrm{CHCl}_{3}$ & Buff & Yellowish grey & Dark brown \\
\hline Picric acid & $\begin{array}{c}\text { Brownish } \\
\text { yellow }\end{array}$ & Yellowish brown & Black \\
\hline
\end{tabular}

Table 4: Fluorescence analysis of Wedelia trilobata L. Root powder.

\section{Discussion}

To assure the reproducible quality of herbal drugs, proper control of starting material is vital. The primary step towards ensuring starting material is authentication. Thus, in recent years there has been a rapid increase in the standardization of medicinal plants. Though modern techniques are available, but still identification of medicinal plants is more reliable on pharmacognostic studies [24]. In this regard, the macroscopic and microscopic features of root have been studied. Macroscopical characters of the root of the plant can serve as a diagnostic parameter. Microscopical study and powder analysis of the plant sample revealed the presence of cork cells, lignified spiral vessels and parenchymatous cells. Further, this study can also be useful to reduce the possibilities of adulteration of this useful herbal drug when it is available in the powdered form [25]. Studies of physicochemical parameters can serve as an important source to judge the purity and quality of crude drugs. The extractive values give the approximate measure of their chemical constituents and from the study, the extractive values of water were highest followed by alcohol. The ash value represents the earthy matter or inorganic components and other impurities present along with the herbal drug. The pharmacognostic standard for the root of Wdelia trilobata L. laid down for the first time in the study. The phytochemical investigation of different solvent extracts viz., chloroform, ethanol and water were examined and it revealed the presence of flavonoids, tannins, phenols, saponins, steroids, carbohydrates and glycosides.

\section{Conclusion}

The data generated from the current study facilitate to authenticate the medicinally important plant $\mathrm{W}$. trilobata. Microscopic features could also be useful for establishing the pharmacopeia standards. Morphology as well as various pharmacognostic aspects of the root of $\mathrm{W}$. trilobata was studied and described along with phytochemical and physicochemical parameters that can be useful in further isolation and purification of medicinally important compounds.

\section{References}

1. Sridharan S, Gounder SC (2016) Pharmacognostic Standardization and Physicochemical analysis of the leaves of Barleria montana Wight \& Nees. Asian Pacific Journal of Tropical Disease 6(3): 232-234.

2. Lowe S, Browne M, Boudjelas S, De Poorter M (2000) 100 of the world's worst invasive alien species: a selection from the global invasive species database: Invasive Species Specialist Group Auckland.

3. Wu W, Zhou RC, Huang HR, Ge XJ (2010) Development of microsatellite loci for the invasive weed Wedelia trilobata (Asteraceae). Am J Bot 97(11): 114-6.

4. Madhava Chetty K, Sivaji K, Tulasi Rao K (2008) Flowering plants of chittoor district. Andhra Pradesh, India 169: 201.

5. Barrett B (1994) Medicinal plants of Nicaragua's Atlantic coast. Economic Botany 48(1): 8-20.

6. Coe FG, Anderson GJ (1996) Screening of medicinal plants used by the Garifuna of Eastern Nicaragua for bioactive compounds. J Ethnopharmacol 53(1): 2950 .

7. Ma BJ, Wen CN, Gao Y, Ren FC, Wang F, et al. (2013) ent-Kaurane diterpenoids from the plant Wedelia trilobata. Nat Prod Bioprospect 3(3): 107-111.

8. Balekar N, Nakpheng T, Katkam NG, Srichana $T$ (2012) Wound healing activity of ent-kaura-9 (11), 16-dien-19-oic acid isolated from Wedelia trilobata (L.) leaves. Phytomedicine 19(13): 1178-1184.

9. Bohlmann F, Ziesche J, King RM, Robinson H (1981) Eudesmanolides and diterpenes from Wedelia trilobata and an ent-kaurenic acid derivative from Aspilia parvifolia. Phytochemistry 20(4): 751-756. 


\section{Open Access Journal of Pharmaceutical Research}

10. Mizokami SS, Arakawa NS, Ambrosio SR, Zarpelon AC, Casagrande R, et al. (2012) Kaurenoic acid from Sphagneticola trilobata inhibits inflammatory pain: effect on cytokine production and activation of the NO-cyclic GMP-protein kinase G-ATP-sensitive potassium channel signaling pathway. Journal of Natural Products 75(5): 896-904.

11. Li Y, Hao X, Li S, He H, Yan X, et al. (2013) Eudesmanolides from Wedelia trilobata (L.) Hitchc. as potential inducers of plant systemic acquired resistance. J Agri Food Chem 61(16): 3884-3890.

12. Qiang Y, Du DL, Chen YJ, Gao K (2011) ent-Kaurane Diterpenes and Further Constituents from Wedelia trilobata. Helvetica Chimica Acta 94(5): 817-823.

13. Ton That Q, Jossang J, Jossang A, Nguyen Kim PP, Jaureguiberry G (2007) Wedelolides A and B: Novel Sesquiterpene $\delta$-Lactones, (9R)-Eudesman-9, 12olides, from Wedelia trilobata. The Journal of organic chemistry 72(19): 7102-7105.

14. Taddei A, Rosas-Romero AJ (1999) Antimicrobial activity of Wedelia trilobata crude extracts. Phytomedicine 6(2): 133-134.

15. Venkatesh U, Kollur SP, Javarashetty C, Jayarama S, Murari SK (2016) Methanolic Extract of Wedelia trilobata in Antiproliferation and Apoptotic Activity. Natural Products Chemistry and Research 4(2): 1-5

16. Balekar N, Katkam NG, Nakpheng $\mathrm{T}$, Jehtae $\mathrm{K}$, Srichana T (2012) Evaluation of the wound healing potential of Wedelia trilobata (L.) leaves. Journal of Ethnopharmacology 141(3): 817-824.
17. Tambe VD, Nirmal S, RS J, PB G, RD B, et al. (2006) Anthelmintic activity of Wedelia trilobata leaves (Asteraceae) 27-29.

18. Khandalwal K, Sethi V (1999) Practical Pharmacognosy Techniques and Experiments. Nirali Prakashan pp: 146-148.

19. (1998) Organization WH Quality control methods for medicinal plant materials.

20. Kokate C (1986) Practical pharmacognosy. Vallabh Prakashan, New Delhi pp: 111.

21. Harborne A (1998) Phytochemical methods a guide to modern techniques of plant analysis: springer science \& business media.

22. Raaman N (2006) Phytochemical techniques: New India Publishing.

23. Patil $P$, Venkatanarayanan $R$, Argade $P$, Shinde $P$ (2012) Assessment of pharmacognostic and phytochemical standards of Thespesia populnea (L.) root. Asian Pacific Journal of Tropical Biomedicine 2(3): 1212-1216.

24. Shah G, Chawla A, Baghel US, Rahar S, Singh PS, et al. (2013) Pharmacognostic standardization of leaves of Melaleuca leucadendron. Pharmacognosy Journal 5(4): 143-148.

25. Alam F, Najum us Saqib Q (2015) Pharmacognostic standardization and preliminary phytochemical studies of Gaultheria trichophylla. Pharm Biol 53(12): 1711-1718. 